Ирина Антанасиевић

Универзитет у Београду

antiira@mail.ru

https://doi.org/10.18485/ai_san_o_gradu.2019.ch4

741.5(497.1)"19"

\title{
САТИРИЧНА СЛИКА РУСКЕ ЕМИГРАЦИЈЕ У ЈУГОСЛОВЕНСКОМ СТРИПУ ТРИДЕСЕТИХ ГОДИНА
}

У раду се описује феномен настанка стрипа о руским емигрантима у Краљевини Југославији, који су чинили одређени културолошки тип, интересантан и за истраживаче стрипа и за социологе, културологе и наратологе. Уколико нам се могућност анализе стрипа као одређеног текста, обједињеног системом културних маркера / кодова, специфичних како за београдску, тако и за емиграцију уопште, учини занимљивом, онда ћемо бити у могућности да разумемо овај текст свакодневног живота, који је настао не само у средини првог таласа руске емиграције, већ и земље која их је прихватила. И не само што је настао, већ је био изложен високом степену митологизације, стварајући сопствене типолошке моделе.

Кључне речи: руска емиграције, стрип тридесетих година, Краљевина Југославија, типологија лика, поетика стрипа.

Покушај анализе сатиричних новинских чланака као одређеног текста, обједињеног системом културних кодова, специфичних како за београдску, тако и за руску емиграцију уопште, приближава нас разумевању тог свакодневног текста, који не само да је настајао у земљи која је примила први талас руске емиграције, 
већ је и био изложен виском степену митологизације, стварајући сопствене типолошке моделе. Као што је познато, у контакту са туђом културом, код човека се неизбежно јавља тзв. когнитивна дисонанца (Фестингер, 1999) и да је наутрализовао, човек мења своје понашање, тј. покушава да се прилагоди окружењу. Ако му из било ког разлога не пође за руком, долази до тзв. културолошког шока - осећаја физичке и емоционалне неугодности. Краљевина Срба, Хрвата и Словенаца, а затим и Краљевина Југославија, урадиле су много да се руске избеглице не осећају као странци. О томе читамо у одломку из успомена Н. Роншчина:

И ево, ту смо. Ма какав је то запад, кад се град зове Београд - Бели Град и када се главна зграда на његовом главном тргу висока кућа у облику брода са кулама и шиљцима зове „Москва“, и када је краљ у прошлости био руски ђак? И на натписима су руска слова, иако је начин слагања необичан за око... брзо смо се навикли. У ствари, шта може да буде тешко, кад се нож на српском каже - нож, человек - човек, женшчина - жена? Треба само да се намести језик као за школски црквенословенски и све ће ићи као подмазано. А колико је тога руског! Па и ти натписи над мрачним улазима „кафан“, у којима у високим бачвама спава густо, јако вино. Свако трговинско предузеће има свој покровитељски мото. Попут „код генерала Скобељева“, „код белог Цара“, „код веселог Руса“... и сам сам видео натпис у малом граду „код Петра Степановича, кијевског спахије“. Многи су отишли. Комвој за комвојем - десет, двадесет, тридесет хиљада Руса, отераних ватром Грађанског рата. И убрзо своје новине, комитети, канцеларије и, наравно, безброј „Рјурика“, „Варјага“, „Асторија“ са руским балалајкистима, са самоваром на столу, са лењим варењикама и сибирским пељменима. И за папириће који још јуче нису ништа вредели, већ их је носио ветар и покривао палубу брода, данас дају пуноправне, праве динаре, и после милиона за прокријумча- 
рену пљескавицу од псећег меса, за лошу харингу, кутију шибица - излози који се ломе од свакојаког заборављеног добра, и миран, пријатан бас: „Само изволите, за батушке попуст, може и на вересију!“ (Рошчин 1932)

На овакву атмосферу утицале су и одлуке Југословенске владе, која је 1928. године, на основу споразума Министарства спољних послова Југославије и Министарства просвете, са Комисијом за руске избеглице основала Руски културни комитет (РКК), који је требало да створи институције од значаја за живот руских емиграната „без којих се руски интелигентни човек осећао истргнутим из културног живота - науке, књижевности и уметности, у коме је он заузимао достојно... место“ ( Косик 2007).

Већ 1922. године министарски савет донео је одлуку да се све руске избеглице изједначавају у правима на плату са својим југословенским колегама. Ситуација се донекле изменила и погоршала након убиства краља Александра Првог Карађорђевића у Марсељу. У писму В. Н. Штрандмана од 1. септембра 1936. године, принцу-регенту Павлу је речено: „Министарство унутрашњих послова одбија да емигрантима додели југословенско држављанство, што их лишава права да остваре зараду, чак и у страним предузећима, којим се налаже да дају предност домаћим радницима..." (Переписка ... 36. докумената, 1998), али у основи руске избеглице у Југославији осећају подршку, како власти, тако и становништва. И што је веома важно, свакодневни процес међукултурне трансформације, који је по правилу прилично трауматичан, повезан са интеграцијом у туђу културну средину и стварањем нових маркера идентичности, код руских избеглица у Југославији није био толико изражен: културолошке разлике 
је наравно било, чак и више него што се на први поглед чинило, али она није изазивала велику нелагодност, већ је омогућавала стварање удружења и живот у оквирима уобичајеног поља самоидентификације: „У Београду можете не само слободно да се служите руским језиком, већ и да у потпуности живите у атмосфери 'рускости'. Нема државне установе у којој на различитим положајима не би радили Руси.“" (Иллюстрированная Россия 1932).

Тако серија прича (у руским сатиричним новинама „Бух!“) писца В. Брандима: Србин о Русима (у № 4) и Како су Руси освојили Београд (у № 20) иронично описује „окупацију“ Руса, где је перцепција емиграције као инвазије представљена, па и у ироничном кључу, прилично суптилно. Описујући сопствену земљу, коју довитљиво назива Краљевином Срба, Хрвата, Словенаца и Руских избеглица, Брандим пише: „Шта су нам дали Руси? Руски балет, руску салату, руску балалајку, руске табакере од руске платине, руске аристократе, руске иконе и обичај да се женама љуби рука. Шта су Руси од нас узели? Ракију, вештину псовања, државни посао са каквом таквом платом, а они који су оженили наше девојке - и мираз“ (№ 4). Описујући изобиље Руса у Краљевини, Брандим наравно претерује, али у тој гротески нема непријатељства: „...Некада сам хтео да одем у Русију и да мало поживим са Русима. Сада за тим нема никакве потребе. Ујутру ми новине доноси Рус. После њега се појављује млекар - Рус. У продавници уље и јаја купујем од Руса. Цигарете ми на киоску продаје Рус. У трамвају слушам руски. У канцеларији се читав персонал потчињава само нашој дактилографкињи - Рускињи. Једем руску салату за вечеру у ресторану 'Руска лира', слушам руске балалајке и руске песме. Служи ме конобар Рус. Пијем ру- 
ску вотку и напијам се као Рус и кући ме вози шофер, поново Рус“ (№ 4).

Јасно је да су револуционарни догађаји у Русији и појава великог броја руских емиграната у Европи условили много социјалних феномена у рецепцији догађаја које је неопходно узети у обзир. Руски свет, сударивши се са другим културолошким моделом и нашавши се у процесу свакодневне међукултурне трансформације, тј. у процесу увек прилично трауматичном, повезаном са интеграцијом у туђу културну средину и израдом нових маркера идентичности, наравно није се могао тако лако навићи на ново стање ствари. Али и прихватне земље такође су пролазиле кроз процес адаптације на руску емиграцију. За Србе је он био посебно тежак, с обзиром на то да је нарушавао или у потпуности рушио вековима постојеће представе о Русији и Русима. Отуда је понекад долазило до неслагања са неким облицима живота руске емиграције, за које су такође кривили руску револуцију, која је покварила „праве Русе“. А неслагање је утицало на појаву критичких и сатиричних материјала. 


\section{Београлсkе беле ноћи наших Коља и Волођа...}

\section{у Беотраду fom увег белm Pуси биpajy губернаторе за pyсију}

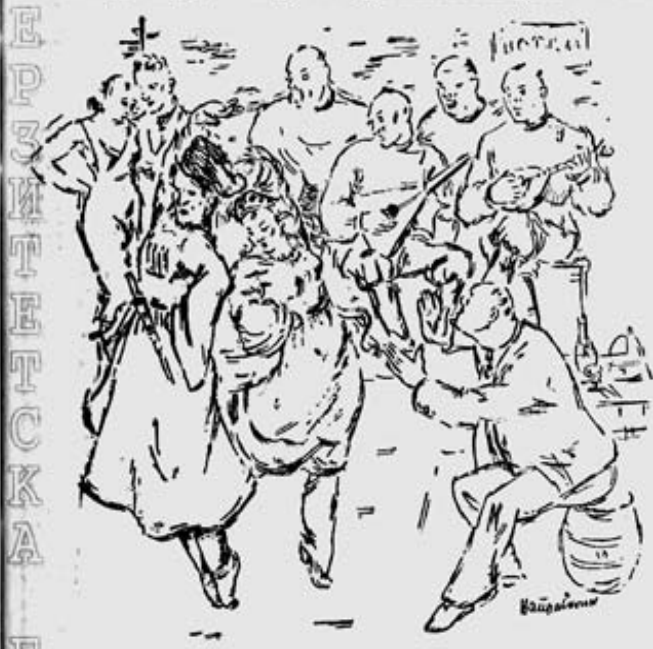

1. woy oео метрозрадске 6еле коһu. Tо су беorpaдcke. H те 6еотрадске 6еле nohu cy saro bene wro one ocuer raaajy wu. eor pуских Genozapдejaya којu, Geз Марсо.

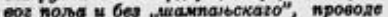

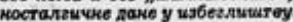

Oee noku Pyca y Beozpary moxna cy untrepcantruje - oz oviux crapux y ПIетроzpary'u nezoenu nokмtu nокалима.

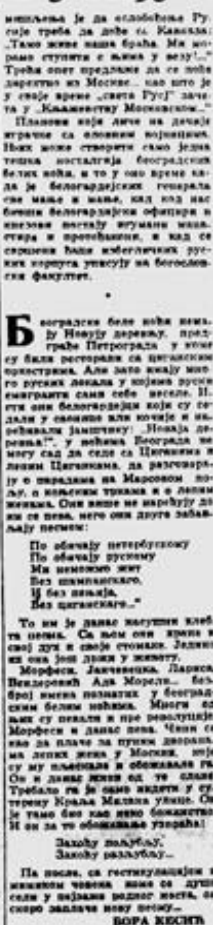

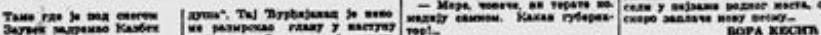

Сл. 1. У листу „Време“ од 28. јуна 1937. год. изражава се чуђење што у Београду Руси још увек бирају губернаторе.

Не може се рећи да је руска емиграција у Југославији, земљи пријатељски настројеној и словенској, била поштеђена размирица са локалним становништвом. На пример, 1932. године у листу „Jugoslovenska politika“ 
појавио се низ материјала Д. Павићевића, у коме је он, намерно претерујући, покушао да оштро супротстави раскош Руса и немаштину Југословена. О томе сведоче наслови чланака, попут: „Руси се госте, наши гладују“, „Руси нас даве“, „Руси су побеснели“ (Косик 2007).

Фебруара 1937. године делегација српских представника посетила је директора „Радија А. Д.“, генерала Калафатовича и изјавила је следеће: „Ми, Срби, у својој кући дозвољавамо себи да вређамо Русе, оне Русе који су за време европског рата бранили Београд и погинули на Солунском фронту... Али да оставимо мртве, просто је недостојно да Срби вређају ону браћу Русе, који се сада у беди, изгубивши своју домовину, муче и пате по целом свету... Постоје две нације без отаџбине - Руси и Јевреји. Међутим, из неког разлога, нападају само Русе“ (Маевский 1966). Ипак данас, анализом радио емисије које су остале забележене у виду штампаних брошура (издавачка кућа Т. Костића из Београда, 1937. год), морамо закључити да су пре свега описиване разлике културолошког карактера, будући да су Србима били необични и обичаји за Масљењицу, и руске традиције, и ресторански живот, а сметала им је гордост емиграната, који су се бранећи се од стварности, понекад исувише нападно, сећали лепота из прошлости, уздишући што су сада у таквој сељачкој провинцијалној Европи.

А данас нас насмеје, каткад чак и разнежи, оно што је понекад изазивало неразумевање Руса и Срба, којима су са развијеним патријархалним системом односа били чудни многи облици свакодневних, породичних односа.

На пример, у новинама „Време“ из 13.08 1934. год. појављује се оваква белешка: 


\section{РУСКИ МУЖЕВИ}

Бes passora ce ranasajy nojeаиви мужеви Рускива. Они су у Русији бими мужеви као и сви прави мужеви. А што их код иас третирају „папучиһима" томе су узоок приияе.

Hanprosep, moj cyces je $P_{y c}$. Стари тосподин. Њerosa rocnoha и khn су запослене. Он сврша sa no kyhn somahe nослове и изванредно кува. А зиате АИ шта је 6но у Русији? Чин у војсии: генерах. Зваве: Губариатор. Ми слим аa иесете помислити aа је губернатор гарнизона кувао „6оршч" п У Русији.

Дакле, као што видите саи Py си нису "папучиһи". Прияике, под којима они живе, такве су. A. $\mathrm{M}$.

\section{Сл. 2. Руски мужеви}

Серија новинских фељтона и делова стрипова сатиричног карактера изнедрила је културолошки тип, такозваног „Серјожу“, који се појавио у периоду од 1933. год. (као јунак радиодраме Београдског радија) и заједно је са женом Ниночком одмах постао јунак анегдота, новинских чланака, радиодрама, позоришних представа. Излазиле су чак и књижице које су се врло радо куповале на киосцима.

Редакција листа „Време“ је искористила ту популарност и урадила чак и „интервју“ са, како је у наслову истакнуто, најпопуларнијим Русем у Београду. 


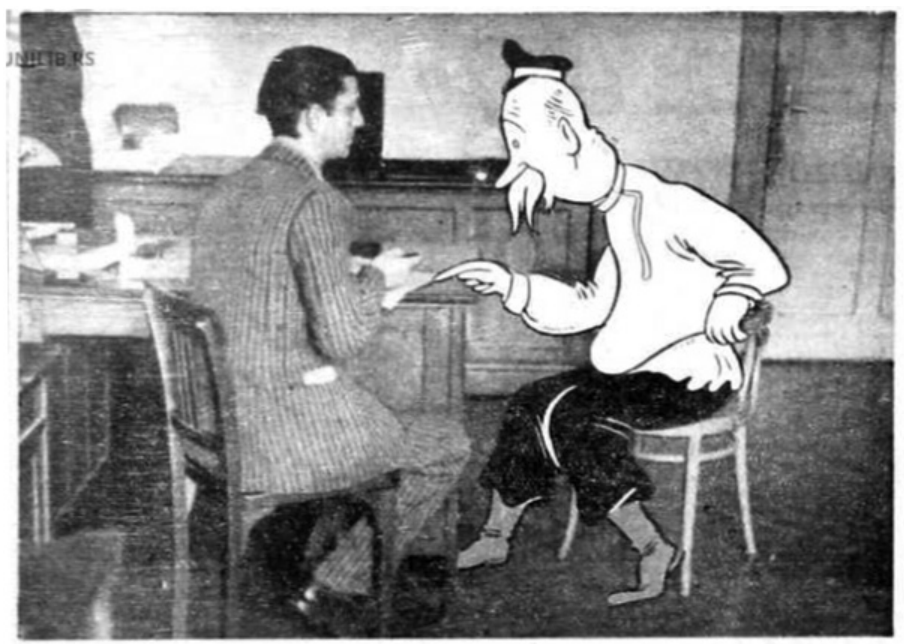

мy

\section{Iрви сусрет са најпопуларнијим Русом у Београду \\ Серјотом - Ниночкиним мужем}

И овај лист је започео најпре серију о заљубљеним јунацима, а затим је и Серјожу, Ниночку и њиховог друга Аркадија учинио јунацима стрипа.

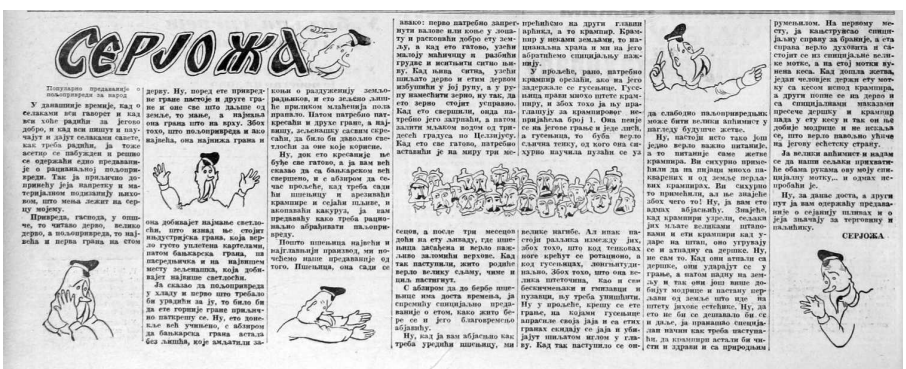


OА СУТPA Y „Времену“ почиње излазити Серјожин оригиналан стрип

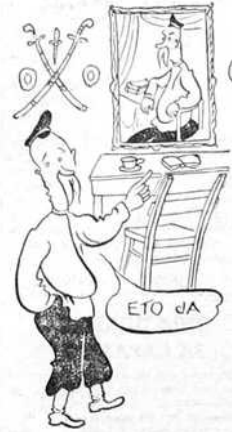

Серјожка је одржао реч. ДІотио је у редакцију. Заиете частая чо-

век. ния очима. Н туно молбености. Тешко је ланас бити беспослен. Tихо je закуцао на врата
скоро нечујно ушао унутра. скоро нечујно ушао унутра. Ниночка.... Мнохо: - биле су ниночка... Мнохо:

трве речи Серјожине.

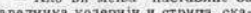

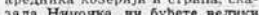
эала ноло

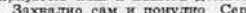

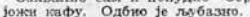
Понугто сам sту чаз. Th fe preto кационалио mиhе, Замекслите, в то је одбио. Тадв сам се наттатио 8 тредложио Серіожи ноду. - Ну, вотку можно! - ттиетво je Серјожа и као да се осмехану. Ment није нитта друго остало. beh za uecto poze - मоручry Boткy.

A нешrто кастије, Cepjoska je отворно евоје срне.

- Ja cmarr Ниточкr. Oia радосна, знајеће, как рыңосна. И

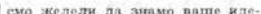
ско желели да зимано ваше кде-
је. које һете спроводитн. Je, $-\mathrm{Hy}_{\text {, }}$ soje идеje... Ja pacmpasљahy разљичита mrтан: вели, елерту. ин жестьy, $\mathrm{Ha}$ upusep, сугчаних пега на рат у ішинян. ји, о моди, в асему помто ето me maja eneurujamroer. 3rajehe, ја вам çasao 6r пуио етих различитих идеји. али ја имао иокуство... Мена били пожралт идејн и оство без нх.

- Најзал Серjoжа. добро he бкти. пошто ступате юод нас' кае урединк једяе рубрике, an повремено уияте й научите боље наш језия. To he бити лакmе за tac и читаоце.

Ja sнajy, ja sнnjy! Пошто ви Серби за петначет годин не научили па руеси, ја прияуыен научит се сертеки. Ja змају цртати и завтра за пряи пут принееу нови етрит. Or бурет 3900 ce "Серјожа”.

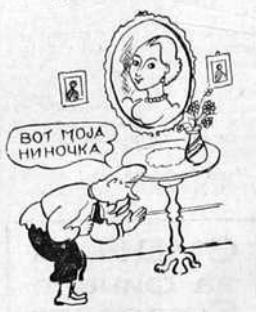

- Значи, ви већ од сутра ету.

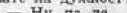

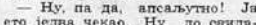
вија!

Према Сердожиятом обеһану, sорамо своје интересова⿴囗十⺝ продугенти до сутра. $\mathbf{y}$ сутратињем ригинатая "Вемена" язтази праи -јожеия.

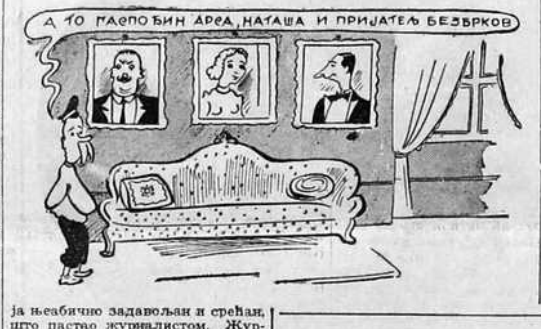

Сл. 3. Најава стрипа 


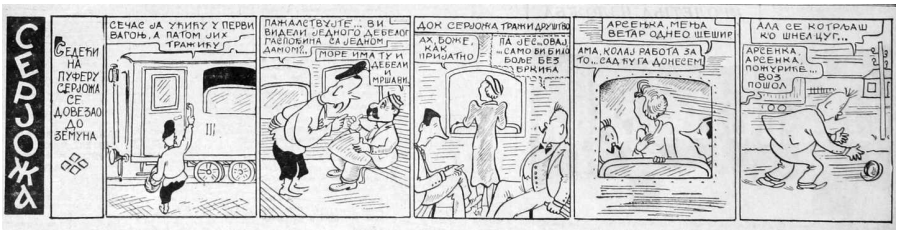

Управо су у лику Серјоже приказане све културолошке разлике, које су изазивале одређене конфликте. Серјожа представља оно што је заједно са Русима дошло у Краљевину и постало део живота: палачинке, салата Оливије, навика испијања чаја (на коју се и сада на Балкану гледа као на типично руски хир), домаће животиње у градским становима, које са укућанима живе у истој просторији (што је за Србе било незамисливо), навика љубљења дамама руке и давања јакне кад постане хладно, а такође и други породични односи (помоћ жени у кућним пословима и сл) - све је то био Серјожа.

Серјожа је бивши пуковник, сада Ниночкин муж и човек који никако не може да схвати да је повратак у Русију немогућ. Серјожа је паметан, али веома наиван, упркос својој памети и животном искуству. И та његова наивност, његова вера у људе и представља половину сижеа, чинећи их не само смешним, већ често и чеховски немилосрдно узнемирујућим. Такав је случај са смешном причом (Т. Костић, „Божићно прасе“), у којој се говори о Серјожи који се за последње паре купио прасе за Божић (не би све било као некад, као у мајчици Русији), ангажује првог Циганина на кога је наишао, даје му прасе и плаћа да му га однесе. Наравно, пуковника Серјожу не интересују документа Циганина јер он добија његову часну реч да ће му однети прасе на адресу. Циганин даје часну циганску реч и нестаје са прасетом заувек, а сироти Серјожа одлази у милицију. И ту долазимо до вероватно најдирљивијег дела читаве 
смешне приче: он не одлази да пријави крађу, одлази јер брине што му Циганин није донео прасе јер му се вероватно нешто десило, можда му је припало тешко, можда се разболео... И никако не може да разуме грохот полицајаца, понављајући само - дао ми је часну реч, частан је човек. Морате да му помогнете...

Серјожина простодушност је наравно претерана, са сатиричном оштрином, али је безазлена и његов лик чини симпатичним и дирљивим.

Није изненађујуће да се баш лик Серјоже - наивног и часног човека, који не разуме лаж и превару, користи у сатиричним причама, не би ли се оштрије приказао недостатак друштвених појава, слабости друштвених структура.

Интересантно је пропратити и развој лика, који је почео као сатира на руску емиграцију, а временом постао огледало југословенског друштва.

Једнако дирљиво и трагично приказана је и избегличка руска машта о повратку кући. На пример, у причи Симе Миличића у листу „Правда“ од 24. септембра 1933. год. - Боже, сачувај цара - читамо гогољевску причу о старом Ивану Ивановичу и његовој жени Ксенији Јевгењевној, у којој се као лајтмотив појављују речи јунака, које понављају у себи као утеху: 


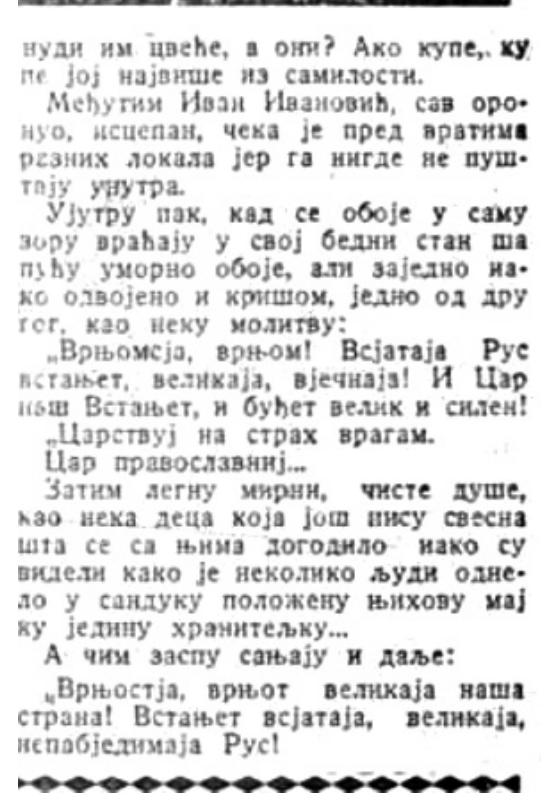

Речи јунака написане су у српској транскрипцији, али на руском. И та молитва, тај утешни сан, овај крхки, простодушан и смешан пар чини дирљивим и задивљујуће упечатљивим. Они су, пише аутор, чисте дечије душе, које не разумеју зашто њихова мајка лежи у тесном сандуку и куда је односе суморни људи. И та трагична нота ову смешну причу чини веома сугестивном и поставља важне оријентире за схватање трагедије која се десила у Русији.

Сатирични есеји о руској емиграцији, као и серија булеварских романа, чији су јунаци били руски емигранти (на пример роман „Татјана“, Божидара Сталиновича, који је излазио у листу „Правда“ од јуна до августа 1933. године) захтева посебно истраживање, које може бити интересантна допуна опште слике културне рецепције руске емиграције у Југославији. 


\section{Извори и литература:}

Антанасиевич И. Русский комикс Королевства Югославия. Нови Сад: Komiko, 2014.

Лободенко Е. МАД, Линский и другие. „Русская карикатура во Франции в период между двумя мировыми войнами“. Крещатик: журнал. - 2014. - № 3 (65). http://magazines.russ. ru/kreschatik/2014/3/44l.html (дата обращения 30.06.2018).

Маевский В. Русские в Югославии. Взаимоотношения России и Сербии. Нью-Йорк. Т. 2. 1966. С. 70-72.

Переписка бывших царских дипломатов 1934-1940. Сб. документов. М.: в 2-х кн. Кн. 1. $1934-1937$.

Рощин Н. Русские в Югославии. По чужим краям. Париж: Иллюстрированная Россия, 1932.

Стайков А. Кратка история на българския комикс. Кибея, София. 2013.

Irina Antanasievich

\section{SATIRICAL IMAGE OF RUSSIAN EMIGRATION IN THE YUGOSLAVIAN COMICS OF THE 1930S}

In the article describes the phenomenon of appearance a comic strip about Russian emigrants in the Kingdom of Yugoslavia, which formed a kind of culturological type, interesting for comics researchers, sociologists and culturologists, and narratologists. Since it seems interesting to us to consider comics as a text united by a system of cultural markers / codes that are specific to emigration in general and for Belgrade emigration in particular, it's will help us to understand the context of everyday life that has developed not only among Russian emigrants of the first wave, but also the context of their host country. It's not just formed, but also began to undergo a high degree of mythologization, creating their typological models.

Key words: Russian emigration, comics of the 1930s, the Kingdom of Yugoslavia, image typology, the poetics of comics. 